\title{
Rapid assessment of tissue nitrogen in cultivated Gracilaria gracilis (Rhodophyta) and Ulva lactuca (Chlorophyta)
}

\author{
DV Robertson-Andersson ${ }^{1 *}$, DT Wilson ${ }^{2}$, JJ Bolton ${ }^{2}$, RJ Anderson 3 and GW \\ Maneveldt4
}

1. Botany Department, University of Cape Town, Rondebosch 7701, South Africa. Present address: Department of Biodiversity and Conservation Biology, University of the Western Cape, Bellville 7535, South Africa.

2. Botany Department, University of Cape Town, Rondebosch 7701, South Africa.

3. Botany Department, University of Cape Town, Rondebosch 7701, South Africa. Present address: Seaweed Research Unit, Marine and Coastal Management, Department of Environmental Affairs and Tourism, Rogge Bay 8012, South Africa.

4. Department of Biodiversity and Conservation Biology, University of the Western Cape, Bellville 7535, South Africa.

* Corresponding author, e-mail drobertson-andersson@uwc.ac.za

\begin{abstract}
Tissue nitrogen content and thallus colour were quantified using a rapid assessment method based on the Pantone $\AA$ matt uncoated formula guide for raft-cultivated Gracilaria gracilis Steentoft Irvine et Farnham at Saldanha Bay and tank-cultivated Ulva lactuca Linnaeus at Jacobsbaai in 2001 - 2002. A relationship between thallus colour and tissue nitrogen, as well as a transition between green-yellows and yellowbrowns that occurs between 0.8 - $1.3 \mathrm{mg} N$ per g tissue (Pantone $\AA$ colours $460 \mathrm{U}-$ $455 \mathrm{U}$ ) for Gracilaria were found, with the green-yellow colour indicating nitrogenstarved material and the yellow-browns indicating nitrogen-replete material. For Ulva a transition between green and yellow-green occurred at a tissue nitrogen content of between 1.5 - 1.7 mg N per g tissue (Pantone $\AA$ colours $585 \mathrm{U}$ and $583 \mathrm{U}$ ). This relationship can be used by seaweed farmers for cultivation management as a quick guide to determine nutritional status of the seaweeds, and as an indication of protein content when the seaweeds are used as feeds.
\end{abstract}

Keywords: cultivated seaweeds, Pantone $®$, tissue nitrogen, thallus colour

\section{Introduction}

Variations in seaweed thallus colour are largely related to varying amounts of pigments (chlorophylls, xanthophylls, phycobilins) and their breakdown products. Studies with Gracilaria, for example, have showed that levels of pigment proteins are closely correlated with tissue nitrogen content (Lapointe and Ryther 1979, Hegazi et al. 1998). This is because the pigment phycoerythrin (a phycobiliprotein) is largely responsible for determining the red colour of the thalli, and the concentration of this 
pigment changes according to the nitrogen content, causing a lightening or darkening of the thallus. In green seaweeds the main pigment proteins are chlorophylls and, in this case, changes in the concentrations of chlorophylls would cause lightening or darkening of the thallus, altering the seaweed's colour.

Thallus colour changes due to changes in tissue nitrogen content in cultured seaweeds have already been documented for Gracilaria spp. (Lapointe and Ryther 1979, Wilson 1999), Caulerpa prolifera (Forsskal) Lamouroux, Jania rubens (Linnaeus) Lamouroux, Padina pavonica (Linnaeus) Thivy (Hegazi et al. 1998), Ulva rigida C. Agardh (Lahaye et al. 1995), Chondrus crispus (Linnaeus) J. Stackhouse (Haxo and Strout 1950, Neish and Shacklock 1971, Harvey and McLachlan 1973, MacKenzie 2003), Euchuma spp. (Neish 2003), Ascophyllum nodosum (Linnaeus) Le Jolis, and several species of Fucus (MacKenzie 2002). Even chlorosis (yellowing due to pigment destruction) of Ulva thalli has been well documented (Turpin 1991, Floreto and Teshima 1998).

However, all these authors use terms such as lighter, darker, bleaching, yellowing and reddening without providing a meaningful description of colour quantification. While some phycologists (e.g. Chamberlain and Keats 1994) have quantified the colour of seaweeds, albeit for descriptive purposes, using the Methuen Handbook of colour (Kornerup and Wanscher 1984) for example, to our knowledge no one has attempted to quantify the relationship between tissue nitrogen content and thallus colour in seaweeds. The aim of this research was to quantify the relationship between tissue nitrogen content and thallus colour for two increasingly important commercial aquaculture species in South Africa, Gracilaria gracilis Steentoft, Irvine et Farnham and Ulva lactuca Linnaeus, in order to provide a means for seaweed cultivators to identify the quality of the seaweeds as a feed source for abalone, Haliotis midae Linnaeus, and sea urchins, Tripneustes gratilla Linnaeus, as well as a fast and economical means of determining seaweed nutritional status for cultivation purposes.

\section{Material and methods \\ Seaweeds and sources of nitrogen}

Gracilaria gracilis was cultivated using suspended cultivation in the sea on rope rafts in Saldanha Bay ( $17^{\circ} 57^{\prime} 16^{\prime \prime} \mathrm{E}, 33^{\circ}$ oo' 04" S, Western Cape) on the west coast of South Africa. Stocking weight was $\pm 30 \mathrm{~g}$ of seaweed to prevent self-shading and minimize competition for nutrients and the seaweeds were suspended at roughly $1 \mathrm{~m}$

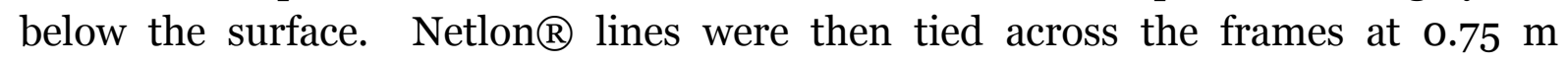
intervals parallel to the line of the prevailing wind direction. For more details on the methods and results of this type of cultivation see Dawes (1995), Anderson et al. (1992, 1996), and Wakibia et al. (2001). The nutrient regime ranged between oligotrophic in summer to nutrient rich in winter and was similar to that reported in Anderson et al (2004). 
Ulva lactuca was cultivated on a commercial abalone farm in Jacobsbaai $\left(17^{\circ} 53^{\prime}\right.$ 12.5" E, $32^{\circ} 58^{\prime} 2.5^{\prime \prime}$ S, Western Cape) just north of Saldanha Bay in $96 \mathrm{~L}$ white PVC tanks $(0.60 \mathrm{~m} \times 0.40 \mathrm{~m} \times 0.40 \mathrm{~m})$. Unfiltered seawater, abalone (Haliotis midae) effluent and turbot (Scopthalmus maximus Linnaeus) effluent generated on the farm were used as the three culture media for $U$. lactuca. These were supplied at 20 volume exchanges per day (see Robertson-Andersson 2004 for a complete description of the cultivation method). The average seawater temperature on the farm was $14.6{ }^{\circ} \mathrm{C}\left(\min 6{ }^{\circ} \mathrm{C}\right.$, $\left.\max 20{ }^{\circ} \mathrm{C}\right)$. The experiments ran from May 2001 to August 2002.

\section{Colour determination}

A total of $2.5 \mathrm{~kg}$ of each of the two seaweeds were grown for two weeks in the various culture media to allow their pigment contents to acclimatize to the culture environment. For colour determination, seaweeds were placed onto white herbarium sheets, blotted dry and their colours determined under fluorescent lighting away from the influence of natural light. The colour chosen was taken as that representative of roughly $80 \%$ of the thallus. Five thalli of each species per culture medium were selected as representative of roughly $80 \%$ of the sample.

The Pantone ${ }^{\circledR}$ colour print formula guide for uncoated matt colours was chosen as a tool to match seaweed thallus colour. Each Pantone ${ }^{\circledR}$ colour has a print guide allowing for reproduction of the exact colours on a desktop PC or at a printer. The corresponding colour code was read from the colour guide that best matched the seaweed thallus colour.

\section{Tissue nitrogen determination}

Representative samples were collected and transported in a cool-box to the laboratory where epiphytes and epifauna were removed. The samples were then washed in deionised water to remove smaller organisms such as isopods and diatoms, oven dried at $50{ }^{\circ} \mathrm{C}$ for 70 hours and ground to $1 \mathrm{~mm}$ particle size using a mechanical grinder. Tissue nitrogen content from the samples of Gracilaria was determined by isotopic analysis at the UCT/ FRD Goldfields Light Stable Isotope Facility (Cape Town, South Africa). Samples were weighed to 1.8 - $2.2 \mathrm{mg}$, sealed in tin capsules and analysed on a Finnigan MAT 252 isotope ratio mass spectrometer with a Carlo-Erba NA 1500 NC elemental analyser employed as a combustion unit. The $\delta^{13} \mathrm{C}$ and $\delta^{15} \mathrm{~N}$ ratios, as well as total $\mathrm{C}$ and $\mathrm{N}$ percentage values were obtained simultaneously. Standards used included Merck gel and the laboratory reference gas was high purity nitrogen (99.995\%) calibrated against atmospheric N. Ulva total tissue nitrogen content was determined using the micro-Kjeldahl technique (Solórzano 1969). 


\section{Results}

For both seaweeds a strong relationship between thallus colour and nitrogen content was visible, with the intensity of the colour indicating the more nitrogen-rich material (Figures 1, 2). In G. gracilis the tissue nitrogen vs. thallus colour showed a transition between green-yellows and yellow-browns that occurred between $0.8-1.3$ mg N per $g$ tissue of the total nitrogen (Pantone $($ colours $460 U-455 \mathrm{U}$ ) (Figure 1), with the green-yellow colour indicating nitrogen-starved material and the deep browns indicating nitrogen-replete material. Similarly, in U. lactuca the transition between green-yellows and green appeared to occur between $1.5-1.7 \mathrm{mg} \mathrm{N}$ per $\mathrm{g}$ tissue (Pantone $\AA$ colours $585 \mathrm{U}$ and $583 \mathrm{U}$ ) (Figure 2).

\section{Discussion}

To our knowledge the relationship between seaweed tissue nitrogen content and thallus colour has not previously been successfully quantified. This study clearly demonstrates that thallus colour can be attributed to the total tissue nitrogen content of the thallus. In addition, the intensity of the colour denoting the algal group (green or red seaweeds) notably provides clues as to the relative amounts of nitrogen in the alga's thallus. These results are supported by Robertson-Andersson (2004) who showed that when $U$. lactuca that was a green-yellow colour (nitrogen-limited) was placed into a nitrogen-rich culture medium, the thallus colour changed from greenyellow to green, whilst the thallus nitrogen content also increased. Alternatively, when dark-green (nitrogen-replete) $U$. lactuca material was placed in a nitrogenpoor culture medium the thallus colour became yellow-green and the thallus nitrogen concentration decreased. This colour response to varying nitrogen concentrations has also been demonstrated for G. gracilis (see Wilson 1999, Njobeni 2006).

Since the accumulation of pigments occurs directly in response to the availability of $\mathrm{N}$ in excess of that required for growth (Lapointe and Ryther 1979, Hegazi et al. 1998), the intensity of the colour that denotes that algal group could be used as a guide to the relative levels of $\mathrm{N}$ in the thallus tissue, and possibly of other secondary metabolites as well. Neish and Shacklock (1971) found that growing Chondrus crispus in conditions of high light and low nitrogen culture media resulted in a higher yield of kappa-carageenan and higher gel strength extracts (called the Neish effect). This relationship has been confirmed for a number of cultivated agarophytes and carragenophytes, and it has been hypothesized that this ripening phenomenon may be related to nutrient storage, in particular of nitrogen (DeBoer 1979, Lapointe and Ryther 1979, Bird et al. 1981, Lapointe 1981, Guist et al. 1982, Patwary and van der Meer 1983, Rotem et al. 1986). It is well known that ripening conditions result in a change in the colour of Gracilaria (Lapointe and Ryther 1979). 
In 2007 seaweeds were the largest cultured marine crop in South Africa, with a total of 1100 tons wet weight being produced (Robertson-Andersson 2007, Bolton et al. 2008). All of this was notably used as feed for abalone, Haliotis midae. The colourscale produced in this study may be useful to mariculture farmers to assess the nutrient value of their seaweeds as a feed for cultivated abalone and sea urchins and this has important benefits for the aquaculture industry as protein-rich sources of feed are constantly being sought. Seaweed farmers wishing to use this tool would place their cultivated seaweeds on a colour chart and be able to read off the nitrogen content and this would provide them with a quick and cost-effective means of assessing their feed quality. Nevertheless, more laboratory work needs to be done to determine the exact switch-over point between nitrogen-replete and nitrogen-starved material.

\section{Acknowledgements}

Funding for this research was provided by SIDA, DEAT, NRF and the UCT. Thanks to A. McLachlan for allowing us the use of his raft and help in collecting material, to D. Kemp and C. Boothroyd who provided assistance in the field, and A.J. Smit and Prof. W.M. Stock for useful communications.

\section{References:}

ANDERSON RJ, LEVITT GJ, DAWES CP AND Simons RH (1992) Experimental growth of Gracilaria in Saldanha Bay, South Africa. In: Mshigeni KE, Bolton JJ, Critchley A and Kiangi G (eds) Proceedings of the First International Workshop on Sustainable Seaweed Resource Development in Sub-Saharan Africa. KE Mshigeni, Windhoek, Namibia, pp 19-36

ANDERSON RJ, LEVITT GJ AND SHARE A (1996) Investigations for the mariculture of Gracilaria gracilis at Saldanha Bay, South Africa. Journal of Applied Phycology 8: 421-430

ANDERSON RJ, SMit AJ AND LeVITT GJ (2004) Upwelling and fish-factory waste as nitrogen sources for suspended cultivation of Gracilaria gracilis in Saldanha Bay, South Africa. Hydrobiologia 398: 455-462 
BIRD KT, HANISAK MD AND RYTHER J (1981) Chemical quality and production of agars extracted from Gracilaria tikvahiae grown in different nitrogen enriched conditions. Botanica Marina 24: 441-444

Bolton JJ, Robertson-ANDERsson DV, SHUUluka D AND KANDJENGo L (2008) Growing Ulva (Chlorophyta) in integrated systems as a commercial crop for abalone feed in South Africa: a SWOT analysis. Journal of Applied Phycology, DOI 10.1007/s10811-008-9385-6

ChamberLain YM AND Keats DW (1994) Three melobesioid crustose coralline red algae from South Africa: Leptophytum acervatum (Foslie) comb. Nov., L. foveatum sp. nov. and L. ferox (Foslie) comb. nov. Phycologia 33: 111-133

DAWES CP (1995) Suspended cultivation of Gracilaria in the sea. Journal of Applied Phycology 7: 303-313

DE BOER JA (1979) Effects of nitrogen enrichment on growth rate and phycocolloid content in Gracilaria foliifera and Neogardhiella baileyi (Florideophyceae). Proceedings of the International Seaweed Symposium 9: 263-271

FlORETO EAT AND TESHIMA S (1998) The fatty acid composition of seaweeds exposed to different levels of light intensity and salinity. Botanica Marina 41: 467-481

Guist GG, DAWES CJ AND CASTLE JR (1982) Mariculture of the red seaweed Hypnea musciformis. Aquaculture 28: 375-384

HaRvey MJ AND Mclachlan J (1973) Chondrus crispus. Nova Scotian Institute of Science, Halifax, Nova Scotia, 155 pp

HaXo F AND Strout P (1950) Nitrogen deficiency and colouration of red algae. Biological Bulletin 99: 360-361

Hegazi MM, Pérez-Ruzafa A, Almela L and CANDela M-E (1998) Separation and identification of chlorophylls and carotenoids from Caulerpa prolifera, Jania rubens and Padina pavonica by reversed-phase high-performance liquid chromatography. Journal of Chromatography 829: 153-159

Kornerup A, Wanscher JH and Pavey D (1984) Methuen Handbook of colour. $3^{\text {rd }}$ Ed. Hastings House, New York, 252 pp.

Lahaye M, Gomez-Pinchetti J-L, Jimenez Del Rio M and Garcia-Reina G (1995) Natural decoloration, composition and increase in dietary fibre content of an edible marine algae, Ulva rigida (Chlorophyta), grown under different nitrogen conditions. Journal of the Science of Food and Agriculture 68: 99-104 
LAPOINTE BE (1981) The effects of light and nitrogen on growth, pigment content and biochemical composition of Gracilaria foliifera v. angustissima (Girgatinales: Rhodophyta). Journal of Phycology 17: 90-95

LAPOINTE BE AND RYTHER JH (1979) The effects of nitrogen and seawater flow on growth and biochemical composition of Gracilaria foliifer var. angustissima in mass outdoor cultures. Botanica Marina 22: 529-539

MacKenZIE D (2002) Dying seaweed in Atlantic Canada reflects nutrient depletion of seawater. http://www.fisherycrisis.com/seaweed4.html accessed: 17 December 2008.

MacKeNZIE D (2003) "Shifting baselines" in marine ecosystems, slow and subtle changes that are hard to notice, but may reveal a lot; a case example: the changing colors of a common red seaweed, Chondrus crispus (Irish moss). http://www.fisherycrisis.com/chondrus/shiftingcolor.htm accessed 17 December 2008.

NeISH AC AND SHACKLOCK PF (1971) Greenhouse experiments on the propagation of strain T4 of Irish Moss. Technical Report. No. 14, National Research Council of Canada, Atlantic Regional Laboratory, 25 pp.

NeISH AC (2003) The ABC of Eucheuma seaplant value Chains: The agronomy, biology, commerce of Betaphycus, Eucheuma and Kappaphycus, the gelatinae, Spinosum and Cottonii of the trade. http://www.surialink.com/abc euchuma/index ABCVC.htm accessed 17 December 2008.

NJOBENI A (2006) Experimental cultivation on the red seaweed Gracilaria gracilis in land-based tank culture systems on abalone farms in the Western Cape, South Africa. MSc thesis, University of Cape Town, South Africa, $131 \mathrm{pp}$.

PATwARY MU AND VAN DER MEeR JP (1983) Genetics of Gracilaria tikvahiae (Rhodophyceae); IX: some properties of agars extracted from morphological mutants. Botanica Marina 26: 295-299

ROBERTSON-ANDERSSON DV (2004) The cultivation of Ulva lactuca (Chlorophyta) in an integrated aquaculture system, for the production of abalone feed and the bioremediation of aquaculture effluent. MSc thesis, University of Cape Town, South Africa, $254 \mathrm{pp}$

ROBERTSON-ANDERSSON DV (2007) Biological and economical feasibility studies of using seaweeds in recirculation systems in abalone farming. PhD thesis, University of Cape Town, South Africa, $327 \mathrm{pp}$. 
Rotem A, ROTH-BEJERANO N AND ARAD SN (1986) Effect of controlled environmental conditions on starch and agar contents of Gracilaria sp. (Rhodophyceae). Journal of Phycology 22: 117-121

SOLÓRZANO L (1969) Determination of ammonium in natural waters by the phenolhypochlorite method. Limnology and Oceanography 14: 799-801

TURPIN DH (199) Effects of inorganic N availability on algal photosynthesis and carbon metabolism. Journal of Phycology 27: 14-20

WAKIBIA JG, ANDERSON RJ AND KEATS DW (2001) Growth rates and agar properties of three Gracilarioids in suspended open-water cultivation in St Helena Bay, South Africa. Journal of Applied Phycology 13: 195-207

WILSON DT (1999) Some aspects of the nitrogen nutrition and growth of Gracilaria gracilis grown by suspended cultivation in Saldanha Bay, South Africa. BSc Honours thesis, Botany Department, University of Cape Town, South Africa, 31 pp

\section{Figure captions}

Figure 1: Relationship between tissue nitrogen $\left(\% \sigma^{15} \mathrm{~N}\right)$ and thallus colour for Gracilaria gracilis (shown by Pantone ${ }^{\circledR}$ matt colour labels). N $=165$.

Figure 2: Relationship between tissue nitrogen (mg. $\mathrm{g}^{-1}$ ) and thallus colour for Ulva lactuca (shown by Pantone $\AA$ matt colour labels). $\mathrm{N}=600$.

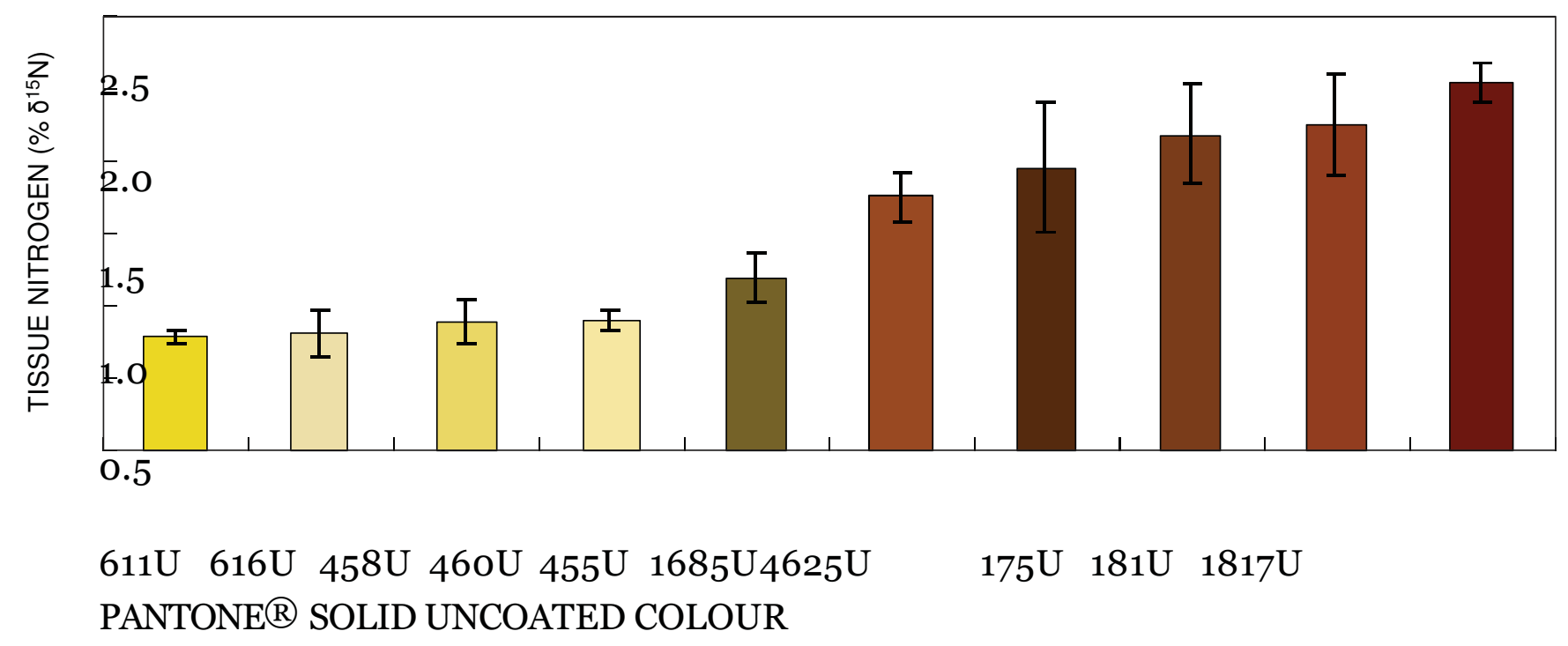

Figure 1: Relationship between tissue nitrogen (\% $\delta 15 \mathrm{~N})$ and thallus colour for Gracilaria gracilis, shown by Pantone ${ }^{\circledR}$ matt colour labels $(n=165)$. Print or 
online representation of the Pantone ${ }^{\circledR}$ colours in the figure is as a precise as technical constraints permit

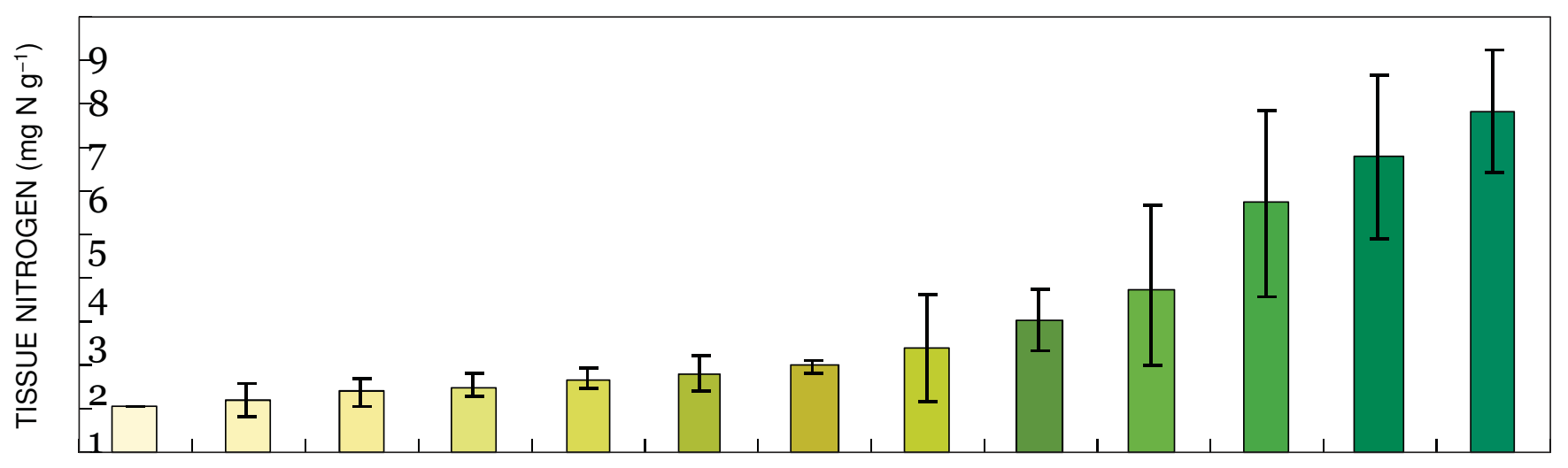

$607 \mathrm{U} 608 \mathrm{U} 609 \mathrm{U} 585 \mathrm{U} 584 \mathrm{U} 583 \mathrm{U} 3975 \mathrm{U}_{390 U} 370 \mathrm{O} 369 \mathrm{U} 362 \mathrm{U} 348 \mathrm{U}$ $3415 \mathrm{U}$

PANTONE® SOLID UNCOATED COLOUR

Figure 2: Relationship between tissue nitrogen $\left(\mathrm{mg} \mathrm{g}^{-1}\right)$ and thallus colour for Ulva lactuca, shown by Pantone ${ }^{\circledR}$ matt colour labels $(n=600)$. Print or online representation of the Pantone ${ }^{\circledR}$ colours in the figure is as a precise as technical constraints permit 